\title{
VARIASI HASIL TANGKAPAN IKAN DARI PERAIRAN SAMUDERA HINDIA, YANG DIDARATKAN DI PPN SIBOLGA PANTAI BARAT SUMATERA TAHUN 2019
}

\author{
(Variation of Fishing in The Hindian Ocean, Landed at PPN Sibolga \\ West Coast of Sumatera in 2019)
}

\author{
Ria R. Manik ${ }^{1 *}$, Ewin Handoco ${ }^{1}$ dan Jogi Arleston ${ }^{2}$ \\ ${ }^{1}$ Jurusan Manajemen Pengelolaan Sumberdaya Perairan, Fakultas Teknik dan Pengelolaan Sumberdaya Perairan, \\ Universitas HKBP Nommensen Pematangsiantar \\ ${ }^{2}$ Dinas Perikanan Kabupaten Batu Bara \\ "riaretnomanik@gmail.com,rayasiantar123@gmail.com,jogiarleston@gmail.com \\ Corresponding author*
}

\begin{abstract}
ABSTRAK: Overfishing dan overcapacity merupakan masalah keberlanjutan pembangunan perikanan tangkap. Indonesia telah mengalami overfishing atau disebut penangkapan berlebih dan overcapacity atau disebut kelebihan kapasitas penangkapan. Pantai Barat Pulau Sumatera memiliki potensi perikanan yang sangat besar, baik perairan teritorial maupun perairan ZEE. Tujuan dari penelitian adalah untuk memahami trend fluktuasi hasil tangkapan ikan di Perairan Barat Sumatera, mengkaji pengaruh trip kapal dengan hasil tangkapan ikan di Perairan Barat Sumatera dan memberikan informasi dasar dan pengelolaan perikanan di Perairan Barat Sumatera. Materi penelitian yang digunakan adalah data Catch per Unit Effort (CPUE). Keseluruhan data merupakan data rata-rata bulanan tahun 2019 dengan daerah fishing ground Perairan Barat Sumatera Samudera Hindia. Hasil penelitian menunjukkan komposisi hasil tangkapan di Perairan Barat Sumatera yang didaratkan di PPN Sibolga terdapat tiga jenis ikan yang dominan yaitu cakalang $14.566 .140 \mathrm{~kg}(49,90 \%)$, layang $6.404 .470 \mathrm{~kg}(21,94 \%)$ dan tongkol $2.480 .880 \mathrm{~kg}(8,50 \%)$, Dinamika hasil tangkapan ikan di PPN Sibolga di tahun 2019 tertinggi terjadi pada bulan Mei sebesar 3.945.143 kg dan bulan Juni merupakan bulan hasil tangkapan terendah yaitu $1.093 .292 \mathrm{~kg}$ dan rata-rata hasil tangkapan bulanan tahun 2019 adalah $2.508 .436 \mathrm{~kg}$, Hasil tangkapan per-unit usaha yang didaratkan di PPN Sibolga di tahun 2019 didapatkan CPUE tertinggi yaitu $8.474 \mathrm{~kg} /$ trip (Juli 2019) dan terendah $1.755 \mathrm{~kg} /$ trip (Juni 2019).
\end{abstract}

Kata Kunci: CPUE, penangkapan berlebih, penangkapan ikan, PPN Sibolga, Perairan Barat Sumatera

ABSTRACT: Overfishing and overcapacity is a problem for the sustainability of capture fisheries development. Indonesia has experienced overfishing or called overfishing and overcapacity or called excess fishing capacity. The west coast of the island of Sumatra has enormous fishing potential, both in territorial waters and in ZEE waters. The purpose of the study was to understand the trend of fluctuations in fish catches in the waters of West Sumatra. Assessing the effect of boat trips on fish catches in the waters of West Sumatra and providing basic information and management of fisheries in the waters of West Sumatra. The research material used is Catch per Unit Effort (CPUE) data. The overall data was monthly average data in 2019 with fishing ground areas in the Western waters of Sumatra, the Indian Ocean. The results showed the composition of catches in the waters of West Sumatra landed in PPN Sibolga there are three dominant types of fish, namely skipjack tuna $14.566 .140 \mathrm{~kg}(49.90 \%)$, decapterus $6.404 .470 \mathrm{~kg}(21.94 \%)$ and tunny $2.480 .880 \mathrm{~kg}(8.50 \%)$, The dynamics of fish 
catches in PPN Sibolga in 2019 were highest in May at $3.945 .143 \mathrm{~kg}$ and June was the lowest catch month of $1.093 .292 \mathrm{~kg}$ and the average monthly catch in 2019 was $2.508 .436 \mathrm{~kg}$, the catch per business unit landed in PPN Sibolga in 2019 obtained the highest CPUE of 8.474 $\mathrm{kg} /$ trip (July 2019) and the lowest 1,755 kg/trip (June 2019).

Keywords: CPUE, overfishing, fishing, PPN Sibolga, West Waters of Sumatera

\section{PENDAHULUAN}

Overfishing dan overcapacity adalah merupakan permasalahan perikanan yang berkelanjutan serta akibat intensifnya tekanan penangkapan, selain itu tekanan penangkapan yang dialami disebabkan oleh perubahan iklim, degradasi sumber daya, polusi, maupun fluktuasi dari harga komoditas serta sengketa batas-batas nasional yang meningkatkan kerentanan bagi nelayan dan keberlanjutan perikanan tangkap (Garcia, et al., 2003; Beddington, et al., 2007; Lieng, et al., 2018; Mamuaya, dkk., 2007; Waluyo, 2009; Fauzi, 2010; Wiyono\&Hufiadi, 2014). Indonesia memiliki peran besar terhadap perikanan tangkap terutama pada bagian produksi. Indonesia telah berkontribusi terhadap hasil tangkapan dunia sebesar 7,19\% (6,54 juta ton) pada tahun 2016 atau satu tingkat di bawah China sebesar 17,56 juta ton $(19,29 \%)$ (FAO, 2018).

Pantai Barat Pulau Sumatera memiliki potensi perikanan yang sangat besar, baik di perairan teritorial maupun di perairan zona ekonomi eksklusif (ZEE). Potensi yang besar tersebut membuat usaha perikanan khususnya usaha penangkapan ikan di pantai Barat Sumatera lebih besar pula dibandingkan pantai Timur Sumatera (Husnah\&Wibowo, 2012; Limbong, $d k k$., 2017). Secara geografis, letak Perairan Sibolga sangat strategis karena berada di Samudera Hindia serta hasil penangkapan ikan kebanyakan didaratkan di PPN Sibolga (Zain, $d k k ., 2011)$.

Penelitian ini bertujuan untuk menganalisis variasi hasil tangkapan ikan di Samudera Hindia Perairan Barat Sumatera yang didaratkan di Pelabuhan Perikanan Nusantara Sibolga. Hasil dari penelitian ini dapat menjadi bahan masukan untuk tujuan pengelolaan dan dasar bagi penelitian lebih lanjut yaitu faktor-faktor yang mempengaruhi hasil produksi tangkapan ikan di Perairan Barat Sumatera.

\section{METODE PENELITIAN}

Penelitian ini dilakukan di Perairan Barat Sumatera (Gambar 1) selama 12 bulan di tahun 2019. Perairan Barat Sumatera merupakan daerah penangkapan ikan yang hasil tangkapannya didaratkan pada PPN Sibolga. Data hasil tangkapan ikan dan kapal penangkap ikan per trip diperoleh dari hasil pencatatan logbook kapal penangkapan ikan di PPN Sibolga.

Data yang diperoleh kemudian dianalisa dengan menggunakan Microsoft Excel 2013 untuk mengetahui trend bulanan hasil tangkapan ikan yang tertangkap di Perairan Barat Sumatera. Produksi ikan yang tertangkap di PPN Sibolga dianalisis menggunakan grafik times series dan diinterpretasikan berdasarkan jumlah terendah dan tertinggi CPUE (catch per unit effort) produksi bulanan ikan yang didaratkan di PPN Sibolga. Tujuan dari perhitungan CPUE adalah untuk mengetahui nilai laju tangkap upaya penangkapan ikan berdasarkan pembagian total hasil tangkapan (catch) dengan upaya penangkapan (effort). Rumus CPUE sesuai dengan Gulland (1983) adalah sebagai berikut:

$$
\text { CPUE } i=\frac{C i}{F i}
$$

$$
\begin{aligned}
& \text { Keterangan: } \\
& \begin{array}{ll}
C i \quad= & \text { hasil tangkapan ke-i (ton) } \\
F i \quad= & \text { upaya penangkapan ke-i (trip) } \\
C P U E i= & \text { jumlah hasil tangkapan penangkapan } \\
& \text { ke-i (kg/trip) }
\end{array}
\end{aligned}
$$




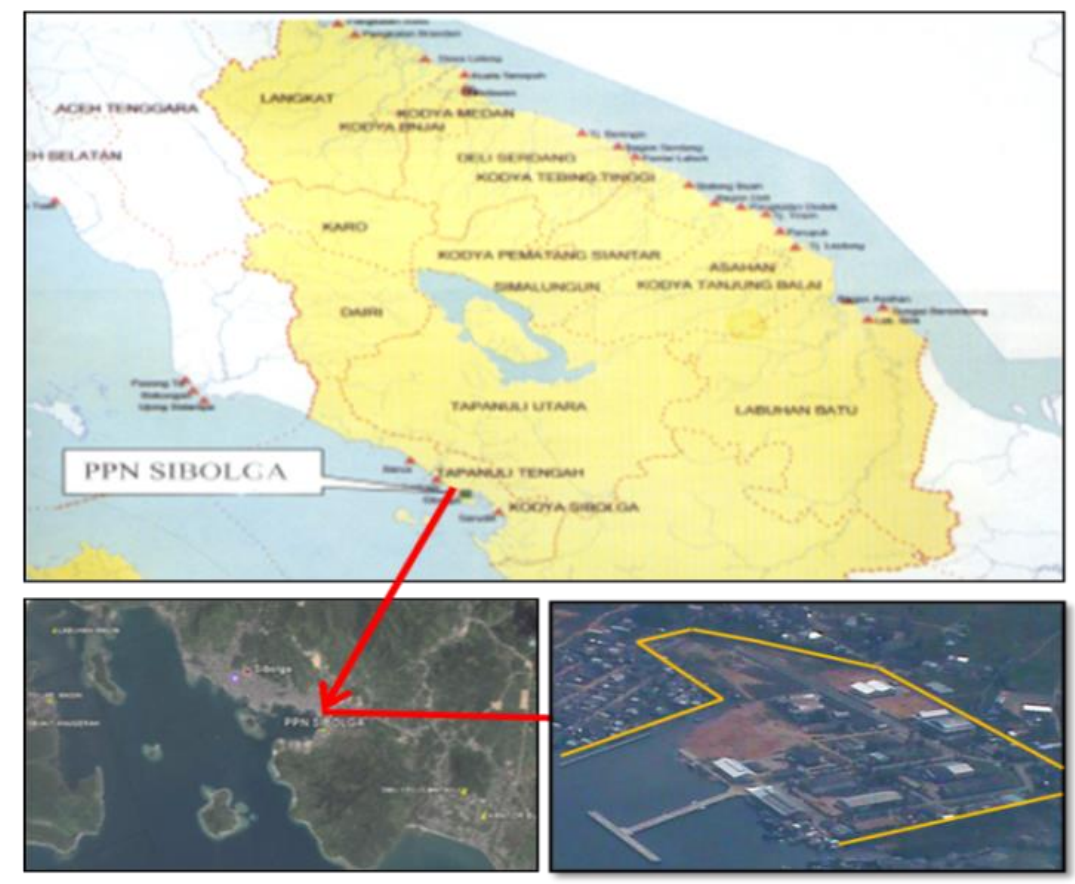

Gambar 1. Peta lokasi penelitian di PPN Sibolga

Analisa standararisasi data CPUE digunakan untuk menstandarisasi semua data CPUE yang ada sehingga diperoleh nilai yang standar untuk memudahkan pembuatan grafik (Sartimbul, $d k k .$, 2013). Rumus yang digunakan yaitu:

$$
\begin{gathered}
s=\sqrt{\frac{\sum_{i=1}^{n}(x i-\bar{x})^{2}}{n-1}} \\
Z=\frac{x i-\bar{x}}{s}
\end{gathered}
$$

Keterangan:

$z \quad=$ nilai standarisasi

$x i=$ nilai $x$ ke- $i$

$\bar{x}=$ nilai rata - rata

$s \quad=$ standar deviasi

$n \quad=$ Jumlah banyaknya data

\section{HASIL DAN PEMBAHASAN}

\section{Komposisi Hasil Tangkapan di Pantai Barat Sumatera}

Berdasarkan hasil penelitian menunjukkan jumlah hasil tangkapan ikan tertinggi di Perairan Barat Sumatera didominasi oleh 3 (tiga) jenis ikan yaitu cakalang (Katsuwonus pelamis), layang (Decapterus sp) dan tongkol (Euthynnus affinis). Secara umum, ikan akalang (Katsuwonus pelamis) adalah jenis ikan yang paling dominan tertangkap di Perairan Barat Sumatera.

Jumlah jenis tangkapan ikan tertinggi (Tabel 1) berturut-turut yaitu cakalang (Katsuwonus pelamis) $14.566 .140 \mathrm{~kg}(49,90 \%)$, layang (Decapterus sp) 6.404.470 (21,94\%), tongkol krai (Auxix thazard) $2.480 .880 \mathrm{~kg}$ $(8,50 \%)$, tembang (Sardinella) 1.972 .730 $(6,76 \%)$, dan madidihang (Thunnus albacares) $1.582 .890(5,42 \%)$. Jenis ikan lainnya yang tertangkap di Perairan Samudera Hindia Pantai Barat Sumatera yaitu ekor kuning (Caesionidae) $1.370 \mathrm{~kg}$, bawal (Pampus argenteus) $1.900 \mathrm{~kg}$, ikan baronang (Siganus sp.) $2.620 \mathrm{~kg}$, selar (Selaroides sp.) $2.910 \quad \mathrm{~kg}$, tenggiri (Scomberomorini) $8.830 \quad \mathrm{~kg}, \quad$ kepiting (Brachyura) 9.960 kg, alu-alu (Sphyraena) $10.220 \mathrm{~kg}$, layur (Trichiurus lepturus) $10.840 \mathrm{~kg}$, peperek (Eubleekeria splendens) $12.770 \mathrm{~kg}$, sunglir (Elagatis bipinnulata) $15.740 \mathrm{~kg}$, talangtalang (Scomberoides lysan) $19.390 \mathrm{~kg}$, udang (Penaeus) $22.280 \mathrm{~kg}$, lemadang (Coryphaena hippurus) $28.020 \mathrm{~kg}$, manyung (Ariidae) 29.900 $\mathrm{kg}$, kurisi (Nemipterus virgatus) $33.890 \mathrm{~kg}$, ayam-ayam (Abalistes stellaris) $45.550 \mathrm{~kg}$, cumi 
cumi (Mastigoteuthis flammea) $56.090 \mathrm{~kg}$, siro (Amblygaster sirm) 78,560 kg, kerapu (Epinephelus) $83.920 \mathrm{~kg}$, tongkol komo (Euthynnus affinis) $99.880 \quad \mathrm{~kg}$, lencam (Lethrinidae) $110.690 \mathrm{~kg}$, kakap (Lutjanidae) $119.640 \mathrm{~kg}$, japuh (Dussumieria acuta) 122.250 kg, kembung (Rastrelliger) $131.670 \mathrm{~kg}$, Kuwee (Caranx) $132.100 \mathrm{~kg}$, tetengkek (Megalaspis cordyla) $150.250 \mathrm{~kg}$, selar bentong (Selar crumenophthalmus) $191.060 \mathrm{~kg}$, pari (Myliobatiformes) $272.900 \mathrm{~kg}$ dan teri (Clupeiformes) $377.980 \mathrm{~kg}$.

Tabel 1. Hasil tangkapan ikan yang didaratkan di PPN Sibolga Tahun 2019

\begin{tabular}{|c|c|c|}
\hline Jenis Ikan & Jumlah Tangkapan (kg) & Persentase (\%) \\
\hline Alu - Alu & 10.220 & 0,04 \\
\hline Kurau & 0 & 0,00 \\
\hline Ekor Kuning & 1.370 & 0,00 \\
\hline Bawal & 1.900 & 0,01 \\
\hline Ikan Beronang & 2.620 & 0,01 \\
\hline Selar & 2.910 & 0,01 \\
\hline Tenggiri & 8.830 & 0,03 \\
\hline Kepiting & 9.960 & 0,03 \\
\hline Layur & 10.840 & 0,04 \\
\hline Peperek & 12.770 & 0,04 \\
\hline Sunglir & 15.740 & 0,05 \\
\hline Talang-Talang & 19.390 & 0,07 \\
\hline Udang & 22.280 & 0,08 \\
\hline Lemadang & 28.020 & 0,10 \\
\hline Manyung & 29.900 & 0,10 \\
\hline Kurisi & 33.890 & 0,12 \\
\hline Ayam - Ayam & 45.550 & 0,16 \\
\hline Cumi Cumi & 56.090 & 0,19 \\
\hline Siro & 78.560 & 0,27 \\
\hline Kerapu & 83.920 & 0,29 \\
\hline Tongkol Komo & 99.880 & 0,34 \\
\hline Lencam & 110.690 & 0,38 \\
\hline Kakap & 119.640 & 0,41 \\
\hline Japuh & 122.250 & 0,42 \\
\hline Kembung & 131.670 & 0,45 \\
\hline Kuwee & 132.100 & 0,45 \\
\hline Tetengkek & 150.250 & 0,51 \\
\hline Selar Bentong & 191.060 & 0,65 \\
\hline Pari & 272.900 & 0,93 \\
\hline Teri & 377.980 & 1,29 \\
\hline Madidihang & 1.582 .890 & 5,42 \\
\hline Tembang & 1.972 .730 & 6,76 \\
\hline Tongkol Krai & 2.480 .880 & 8,50 \\
\hline Layang & 6.404 .470 & 21,94 \\
\hline Cakalang & 14.566 .140 & 49,90 \\
\hline Total & 29.190 .290 & 100 \\
\hline
\end{tabular}


Komposisi hasil tangkapan di Perairan Barat Sumatera Samudera Hindia tahun 2019 didominasi oleh kelompok pelagis besar. Hasil pengamatan menunjukkan ikan dari famili scombridae merupakan jenis ikan yang paling banyak tertangkap di Perairan Barat Sumatera. Salah satu hasil tangkapan penting bagi nelayan di Samudera Hindia yaitu cakalang (Katsuwonus pelamis) (Jatmiko, dkk., 2015). Collette dan Nauen (1983) menyatakan cakalang merupakan highly migratory spesies yaitu memiliki pola ruaya yang jauh dari perairan tropis hingga perairan subtropis. Pernyataan ini juga didukung dengan Supriana, dkk. (2014) yaitu daerah penyebaran ikan cakalang dan tuna di Indonesia meliputi Samudera Hindia, Laut Maluku, Laut Flores, Laut Banda, Perairan Utara Aceh, Laut Sulawesi, Teluk Tomini, Laut Halmahera, Barat Sumatera, Teluk Cendrawasih, Selatan Jawa, utara Sulawesi, dan Laut Arafura. Aziz et al. 1998 menyatakan potensi ikan cakalang (Katsuwonus pelamis) di wilayah Perairan Barat Sumatera yaitu sebesar 64.000 ton per tahun namun pemanfaatan terhadap potensi tersebut baru mencapai $14,6 \%$.

\section{Tren Hasil Tangkapan yang Dominan Tertangkap di Pantai Barat Sumatera}

Jenis hasil tangkapan ikan selama 12 bulan di Pantai Barat Sumatera sangat fluktuatif. Puncak dominasi produksi ikan cakalang terjadi pada bulan Juni yaitu 61,85\% (Gambar 2), selanjutnya puncak dominasi ikan layang terjadi pada bulan Februari yaitu 40,64\%, dan ikan tongkol dengan puncak dominasi terjadi pada bulan November yaitu 16,46\%. Fluktuasi hasil tangkapan di Pantai Barat Sumatera ini dipengaruhi oleh beberapa aspek seperti jumlah kapal, jumlah alat tangkap, adanya regulasi pemerintah serta kondisi alam. Seperti diketahui musim sangat mempengaruhi hasil tangkapan ikan karena pada musim tertentu perubahan kualitas perairan mempengaruhi keberadaan ikan pada suatu wilayah. Hasil tangkapan ikan yang berfluktuasi banyak dipengaruhi oleh beberapa faktor antara lain jumlah upaya penangkapan, keberadaan ikan, dan tingkat keberhasilan operasi penangkapan ikan (Nugraha, 2012). Hal ini ditegaskan oleh Jokoswito (2012) menyatakan hasil tangkapan yang tertinggi pada tahun tertentu, seiring dengan hasil tangkapan yang lebih rendah pada tahun berikutnya.

Secara keseluruhan, produksi hasil tangkapan ikan yang didaratkan pada PPN Sibolga selama tahun 2019 mengalami fluktuasi setiap bulannya. Hasil tangkapan ikan tertinggi terjadi pada bulan Mei sebesar $3.945 .143 \mathrm{~kg}$ dan hasil tangkapan terendah terjadi pada bulan Juni 1.093.292 kg dengan nilai rata-rata hasil tangkapan di tahun 2019 adalah $2.508 .436 \mathrm{~kg}$.

\section{Hasil Tangkapan per Upaya Tangkap (CPUE)}

Jumlah kapal yang melakukan penangkapan tertinggi terjadi pada bulan Juni yaitu sebanyak 623 kapal, sedangkan yang terendah terjadi pada bulan Juli yaitu sebanyak 274 kapal (Gambar 3). Seperti diketahui, nilai CPUE merupakan hasil pembagian dari hasil tangkapan terhadap upaya tangkap yang dilakukan. Nilai CPUE tertinggi yang diperoleh selama tahun 2019 terjadi pada bulan Juli yaitu sebesar $8474,1 \mathrm{~kg} /$ trip, sedangkan nilai CPUE terendah terjadi pada bulan Juni yaitu sebesar $1754,9 \mathrm{~kg} /$ trip (Gambar 4). Berdasarkan data hasil tangkapan diperoleh bulan Mei memiliki nilai tertinggi kedua setelah bulan Juli. Hasil tangkapan melimpah pada bulan ini menyebabkan kecenderungan yang tinggi terhadap upaya penangkapan yang dilakukan pada bulan sesudahnya yaitu bulan Juni. Hasil tangkapan yang rendah serta upaya penangkapan yang tinggi yang terjadi pada bulan Juni menyebabkan rendahnya nilai CPUE pada bulan ini. Keadaan ini disebabkan meningkatnya kompetisi antar armada tangkap yang beroperasi, selain itu juga kapasitas sumberdaya ikan yang terbatas dan cenderung mengalami penurunan akibat kepadatan (densitas) penangkapan yang terus meningkat. Nilai CPUE pada bulan Juli merupakan nilai tertinggi dibandingkan bulan lainnya disebabkan upaya penangkapan yang rendah serta hasil tangkapan yang cukup tinggi menyebabkan nilai CPUE bulan ini tertinggi. Berdasarkan nilai CPUE yang diperoleh, dapat diduga bahwa pada bulan Mei terjadi eksploitasi sumberdaya ikan di Perairan Barat Sumatera yang cukup tinggi sehingga mengakibatkan jumlah hasil tangkapan paling terendah di tahun 2019 terjadi di bulan Juni. 


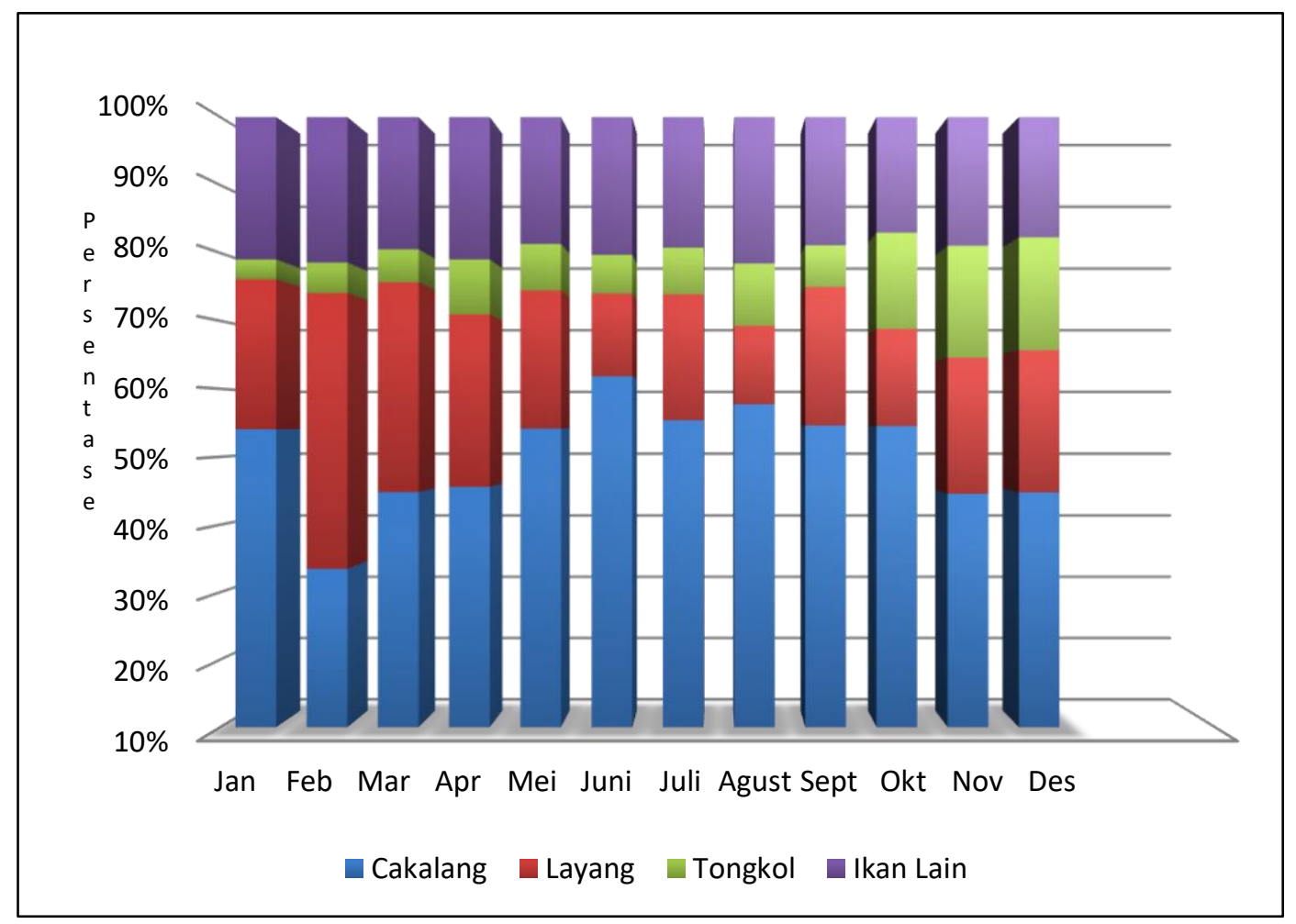

Gambar 2. Grafik bulanan hasil tangkapan di Pantai Barat Sumatera Sumber: Logbook Penangkapan Ikan di PPN Sibolga, (Diolah 2020)

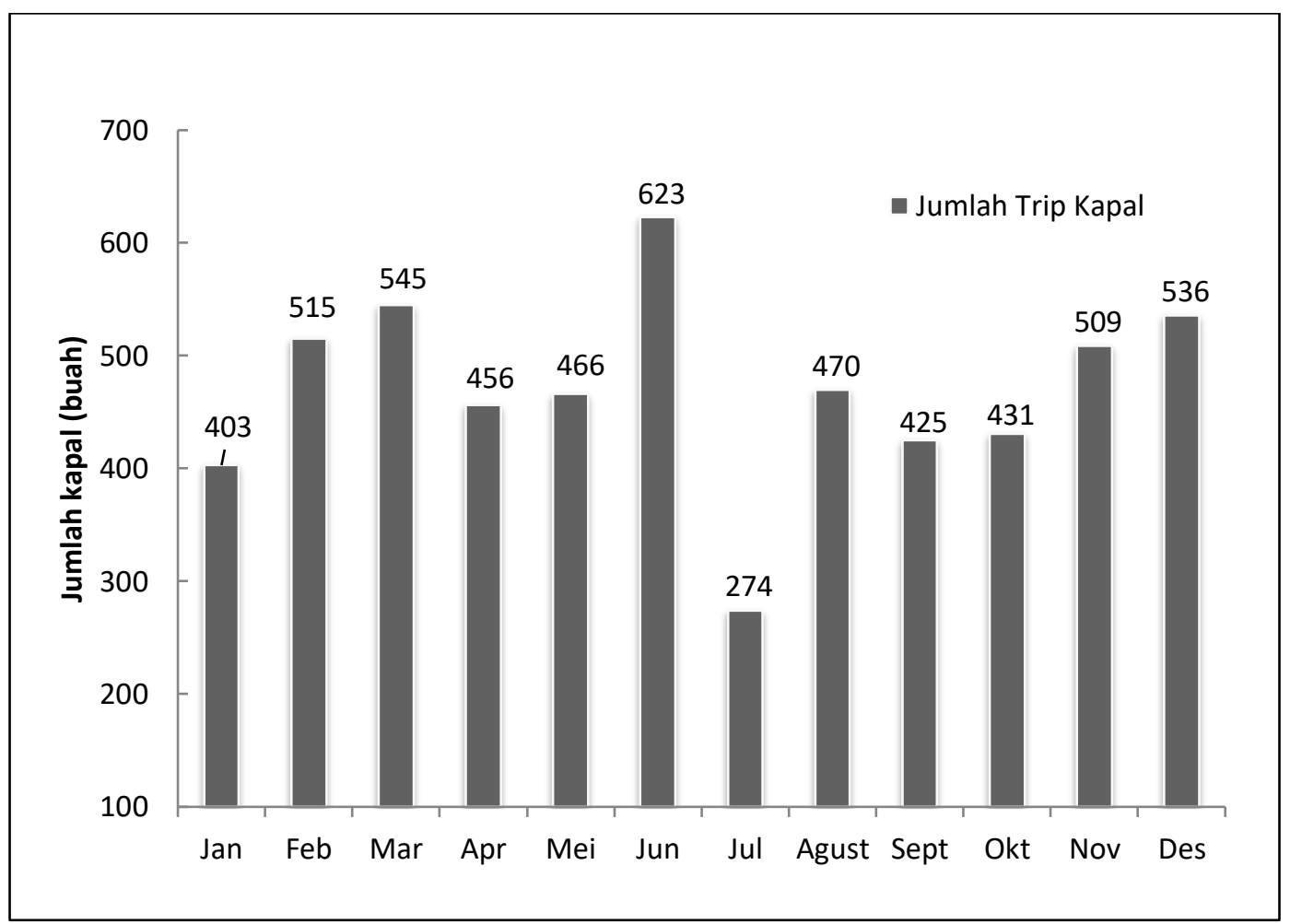

Gambar 3. Kapal yang melakukan penangkapan ikan di PPN Sibolga Tahun 2019 Sumber: Logbook Penangkapan Ikan di PPN Sibolga, (Diolah 2020) 


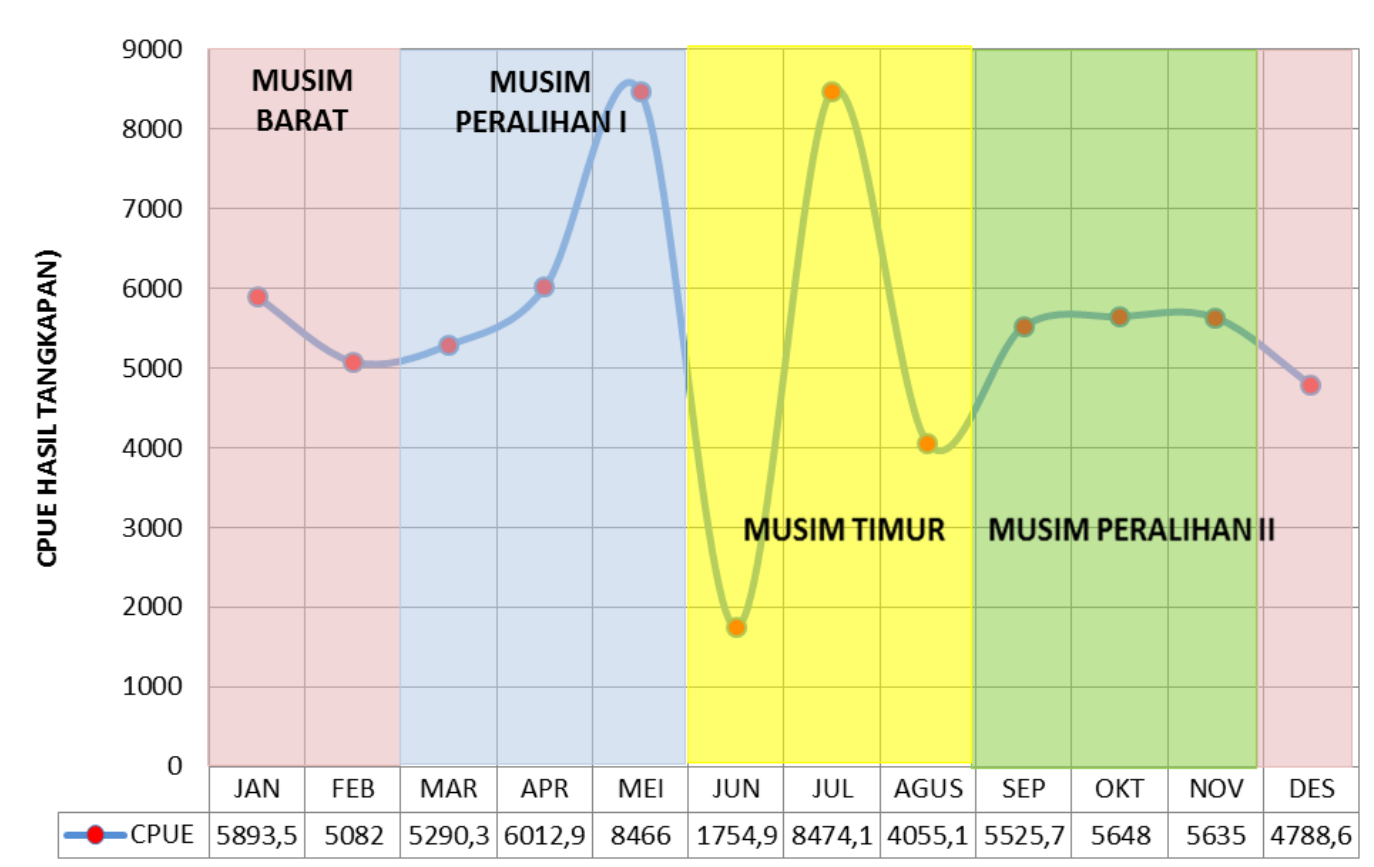

Gambar 4. Hasil tangkapan per upaya (CPUE) di PPN Sibolga Tahun 2019 Sumber: Logbook Penangkapan Ikan di PPN Sibolga, (Diolah 2020)

Jumlah tinggi dan rendahnya produksi hasil tangkapan juga sangat tergantung dari jumlah stok sumberdaya ikan pada lingkungan perairan (Gulland, 1988 dalam Mahmud\&Bubun, 2015). Penambahan stok ikan diakibatkan adanya stok ikan yang memijah, begitupun sebaliknya jika terjadinya penurunan stok ikan pada suatu perairan diakibatkan karena tidak adanya ikan yang dibiarkan untuk memijah dan ditangkap secara terus menerus (Mahmud\&Bubun, 2015). Nilai CPUE mengalami deplesi dikarenakan upaya penangkapan pada tahun sebelumnya sangat tinggi sehingga sumberdaya ikan yang didapatkan menurun di tahun berikutnya. Selanjutnya pada tahun-tahun sesudahnya nilai CPUE akan mengalami kenaikan, karena terjadinya pemulihan sumberdaya ikan (Listiyani, $d k k .$, 2017). Menurut Susanto (2006) menyatakan bahwa pada awal penangkapan terjadi peningkatan nilai CPUE karena bertambhaknya effort dan selanjutnya akan terjadi penurunan nilai CPUE. Lebih lanjut dikatakan bahwa secara ekonomi, keuntungan nelayan akan berkurang dari keuntungan optimal yang diperoleh akibat berlebihnya upaya penangkapan.

\section{KESIMPULAN DAN SARAN}

Komposisi hasil tangkapan di Perairan Barat Sumatera yang didaratkan di PPN Sibolga didominasi oleh tiga jenis ikan yaitu cakalang $(49,90 \%)$, layang $(21,94 \%)$ dan tongkol $(8,50 \%)$. Variasi hasil tangkapan ikan yang didaratkan di PPN Sibolga tahun 2019 tertinggi terjadi pada bulan Mei sebesar $3.945 .143 \mathrm{~kg}$ dan terendah pada bulan Juni $1.093 .292 \mathrm{~kg}$ dengan rata-rata hasil tangkapan adalah 2.508.436 Kg. Hasil tangkapan per-unit usaha yang didaratkan di Pelabuhan Perikanan Nusantara Sibolga di tahun 2019 tertinggi yaitu $8.474 \mathrm{~kg} /$ trip (Juli) dan terendah $1.755 \mathrm{~kg} /$ trip (Juni).

\section{UCAPAN TERIMAKASIH}

Ucapan terimakasih ditunjukkan kepada Fakultas Teknik dan Pengelolaan Sumberdaya Perairan Universitas Nommensen dan Dinas Perikanan Kabupaten Batu Bara. Selanjutnya ucapan terima kasih juga disampaikan kepada Pelabuhan Perikanan Nusantara Sibolga untuk informasi dan data tangkapan ikan, jumlah trip kapal dan data perikanan lainnya. 


\section{DAFTAR PUSTAKA}

Aziz, K.A., Boer, M., Widodo, J., Naamin, N., Amarullah, M.H., Hasyim B., Djamali, A., \& Priyono, B. E. 1998. Potensi Pemanfaatan dan Peluang Pengembangan Sumberdaya Ikan Laut di Perairan Indonesia. Komisi Nasional Pengkajian Sumber daya Perikanan Laut. PKSPL. IPB. Bogor.

Beddington J.R., Agnew J.R., \& Clark C.W. 2007. Current Problems in The Management of Marine Fisheries. Science 316 (5832): 17131716. https://doi.org/10.1126/science.1137362

Collette, Bruce B. and Nauen, Cornelia E. 1983. Scombrids of The World: An Annotated and Illustrated Catalogue of tunas, Mackerels, Bonitos, and Related Species Knwn to Date. Vol. 2. Rome: Food and Agriculture Organization of the United Nations.

Fauzi, A. 2010. Ekonomi Perikanan Teori, Kebijakan dan Pengelolaan. PT. Gramedia Pustaka Utama. Jakarta.

Food \& Agriculture Organization. 2018. Fishery and Aquaculture Statistics 2016. Roma, Italia.

Garcia S.M., Zerbi A., Aliaume C., Chi, T.D., Lasserre G. 2003. The Ecosystem Approach to Fisheries. Issues, Terminology, Principles, Institutional Foundations, Implementation and Outlook. FAO Fisheries Technical Paper. 443. $71 \mathrm{pp}$.

Gulland, J. A. 1983. Fish Stok Assesment: A Manual of Basic Methods. Chichester- New York Brisbane - Toronto - Singapore: John Willey and Sons. $223 \mathrm{p}$.

Husnah \& Wibowo, A. 2012. Karakteristik Sumberdaya Ikan dan Strategi Pengelolaan Perikanan Perairan Sungai Yang Bermuara Ke Pantai Barat Sumatera. Jurnal Kebijakan Perikanan Indonesia 4 (2): 69-78. DOI:http://dx.doi.org/10.15578/jkpi.4.2.2012. 69-78.

Jatmiko I., Hety H., \& Andi B. 2015. Biologi Reproduksi Ikan Cakalang (Katsuwonus pelamis) di Samudera Hindia Bagian Timur. BAWAL 7 (2): 87-94.

Jokoswito. 2012. Potensi Lestari dan Tingkat Pemanfaatan Ikan Kembung Lelaki (Rastrelinger kanagurta) di Teluk Bone. Skripsi. Fakultas Ilmu Kelautan dan Perikanan. Universitas Hassnudin. Makassar.

Lieng S.N., Yagi N., Mori A., \& Hastings J. 2018. Savings-Group Improvements Contribute to Sustainable Community-Fisheries Management: A Case Study in Cambodia.
Sustainability $\quad 10(8): \quad 1-16$. https://doi.org/10.3390/su10082905.

Limbong I., Eko S.W., \& Roza Y. 2017. FaktorFaktor yang Mempengaruhi Hasil Produksi Unit Penangkapan Pukat Cincin di PPN Sibolga, Sumatera Utara. ALBACORE. 1(1): 89-97.

Listiyani A., Dian W., \& Bogi B.J. 2017. Analisis CPUE (Catch Per Unit Effort) dan Tingkat Pemanfaatan Sumberdaya Perikanan Lemuru (Sardinella lemuru) di Perairan Selat Bali. Indonesian Journal of Capture Fisheries. 1 (1): 1-9. www.ejournal2.undip.ac.id/index.php/ juperta.

Mahmud, A. \& Bubun, L.R. 2015. Potensi Lestari Ikan Layang (Decapterus spp) Berdasarkan Hasil Tangkapan Pukat Cincin di Perairan Timur Sulawesi Tenggara. Jurnal Teknologi Perikanan dan Kelautan. 6(2): 159-168.

Mamuaya G.E., Haluan J., Wisudo S.H., \& Astika I.W. 2007. Status Keberlanjutan Perikanan Tangkap di Daerah Kota Pantai: Penelaahan Kasus di Kota Manado. Buletin PSP 16(1), 6478.

Nugraha, S., Koswara, B., \& Yuniarta. 2012. Potensi dan Tingkat Pemanfaatan Ikan Kurisi (Nempterus hexodon) di Perairan Teluk Banten. Jurnal Perikanan Kelautan 3 (1): 9198.

Sartimbul, A., Endang Y.H., \& Erfan R. 2013. Perubahan Iklim dan Perubahan Komposisi Makanan Lemuru ( $S$. lemuru) di Selat Bali dalam Hubungannya dengan Kandungan Omega-3 sebagai Pendukung Ketahanan Pangan. Laporan Akhir Tahun Penelitian Unggulan Perguruan Tinggi. Universitas Brawijaya Malang.

Supriana, A.B., Hascaryo, S.H., Wisudo, M., Baskoro, \& Nikijuluw V.P.H. 2014. Model Rantai Nilai Pengembangan Perlkanan Tuna, Tongkol dan Cakalang di Indonesia. Jurnal Pengolahan Hasil Perikanan Indonesia 17 (2): 144-155.

Susanto. 2006. Kajian bioekonomi sumberdaya Kepiting Rajungan (Portunus pelagicus L) di perairan Kabupaten Maros, Sulawesi Selatan. Jurnal Agrisistem, 2 (2): 55-67.

Waluyo B.S. 2009. Kajian Potensi Perikanan Tangkap dan Pertumbuhan Jumlah Kapal Tangkap (Purse seine) di Kabupaten Pekalongan. Kapal: Jurnal Ilmu Pengetahuan dan Teknologi Kelautan 6 (2): 134-137. DOI: https://doi.org/10.14710/kpl.v6i2.2730. 
Wiyono E. S. \& Hufiadi, 2014 Optimizing Purse Seine Fishing Operations in The Java Sea, Indonesia. AACL Bioflux 7(6):475-482. http://www.bioflux.com.ro/aacl.
Zain J., Syaifuddin dan Aditya Y. (2011). Efisiensi Pemanfaatan Fasilitas di Tangkahan Perikanan Kota Sibolga. Jurnal Perikanan dan Kelautan. 16 (1): 1-11. 